Klaudyna Mikulewicz

Uniwersytet Gdański

\title{
Recenzja książki: M. Manres, N. Real (eds.), 2015, Digital Literature for Children: Texts, Readers and Educational Practices
}

Książka Digital Literature for Children... powstała z inicjatywy Autonomicznego Uniwersytetu w Barcelonie i opisuje wyniki projektu badawczego poświęconego problemowi cyfrowej edukacji literackiej. Badaniu jest poddany wpływ digitalizacji literatury na nauczanie i edukację literacką. Cel publikacji to poprowadzenie przez te zmiany w szkołach oraz wytworzenie strategii włączających multimedia oraz interaktywne teksty i produkty na rynek fikcyjnych dzieł i produktów. Do współpracy zaproszono cenionych badaczy z całego świata, a wśród nich na przykład Bettina Kümmerling-Meibauer czy Junko Yokota z grupy badawczej GRETEL, która powstała w 2004 roku i zajmuje się badaniem literatury dziecięcej w edukacji obowiązkowej, w tym również tekstów w wersji cyfrowej.

Publikację podzielono na pięć części, w których obrębie każdy z autorów opisuje bliskie mu zagadnienia. Część pierwszą zatytułowaną Contextualization and Theoretical Framework (Kontekstualizacja i teoretyczne podstawy ${ }^{1}$ ) otwiera tekst Laury Borràs odpowiadający na pytanie, co oznacza czytanie z ekranów, z punktu widzenia zmian społecznych i kulturowych. Autorka skupia się głównie na czytelnikach dziecięcych, podaje krótki zarys nowych i złożonych mediów oraz nawiązuje do rozprzestrzeniania się form cyfrowej literatury. Kolejny tekst autorstwa Lucasa Ramada Prieto Common Places in Childrens E-Lit. A Journey through the Defining Spaces of Electronic Literature (Powszechne miejsca w elektronicznej literaturze dziecięcej. Podróż przez definiowanie przestrzeni w elektronicznej literaturze) w prowadza $\mathrm{w}$ rozległe obszary wiedzy o literaturze dziecięcej oraz podaje terminologię niezbędną do przedstawienia i zrozumienia konceptu elektronicznej literatury stosowanej do literatury dziecięcej.

Część druga jest poświęcona cyfrowej literaturze dla dzieci i młodych dorosłych. Nie jest to jednak sucha analiza produktów cyfrowych, lecz przede wszystkim refleksja nad ich potencjałem dotyczącym edukacji literackiej. Bettina Kümmerling-Meibauer opisuje wpływ nowych mediów cyfrowych na literaturę dla dzieci i młodzieży, skupiając się przy tym na związku pomiędzy produkcją kierowaną na rynek literatury dziecięcej a elektronicznym medium. W podrozdziale opisano również wzajemny wpływ tych mediów na przykładzie zjawiska

\footnotetext{
${ }^{1}$ Tłumaczenia autorki, o ile nie zaznaczono inaczej.
} 
fanfiction. Junko Yokota zabiera czytelnika w podróż w czasie, opisując przeszłość, teraźniejszość oraz przyszłość cyfrowej książki obrazkowej kierowanej do dzieci. Nacisk jest tu położony na rolę rodziców i nauczycieli w wyborze i ocenie cyfrowych lektur. Autorka opisuje obecny stan publikacji elektronicznych historii dla dzieci w celu porównania ich z papierowymi książkami obrazkowymi oraz opisania różnic w sposobie wpływania na dziecięcego czytelnika. Celia Turrión Penelas przeprowadza dokładną charakterystykę aplikacji narracyjnych, tworząc przy tym dokładny model ich analizy. Opisuje potencjał, jaki ma elektroniczna literatura w procesie zachęcania do czytania i edukacji literackiej. Na wielu przykładach $w$ wyczerpujący sposób przedstawiła tendencje panujące na rynku aplikacji, konstrukcje aplikacji narracyjnej. Autorka stwierdza jednak, że na rynku oprócz wartościowych aplikacji wciąż można znaleźć wiele słabych, prostych dzieł, które nie wykorzystują potencjału tkwiącego w połączeniu narratywnej złożoności z multimodalnością i interaktywnością aplikacji.

Część trzecia skupia się wokół czytelników i literatury cyfrowej. Mireia Manresa analizuje doświadczenia czytelników pięciu cyfrowych dzieł, mając na celu zbadanie poziomu rozumienia elektronicznej literatury oraz sposobów interpretacji cyfrowych zasobów przez trzy grupy dzieci. Autorka zwraca uwagę na dwa punkty centralne wpływające na reakcje młodych czytelników oraz na potrzebę wprowadzenia ich w interaktywne dzieła literackie, które wymagają odmiennych umiejętności niż czytanie drukowanych lektur. Lucas Ramada Prieto i Lara Reyes López tworzą profile czworga młodych czytelników niezaznajomionych z ekranem dotykowym i cyfrowymi lekturami. Dzieci ocenione jako zdolniejsi czytelnicy radziły sobie lepiej również z czytaniem cyfrowych lektur. Pomimo małej grupy badanych po przeprowadzeniu wywiadów z dziećmi autorzy zauważyli ich poszukiwawcze, ludyczne nastawienie podczas czytania cyfrowych wersji. Badania wykazały zapotrzebowanie na pomoc $\mathrm{w}$ zidentyfikowaniu elementów literatury cyfrowej, to znaczy muzyki, ruchu oraz eliminację elementów dekoracyjnych zaburzających rozumienie opowiadanej historii. Martina Fittipaldi, Anna Juan i Mireia Manresa podsumowują ten podrozdział, porównując doświadczenia nastolatków czytających to samo dzieło w wersji papierowej i cyfrowej, którzy wykazują różnice w interpretacji czytanego tekstu. Różnice w interpretacji zostały dokładnie przeanalizowane i szczegółowo opisane przez autorów.

Część czwarta jest poświęcona praktykom edukacyjnym stosowanym zarówno w szkołach, jak i przez rodziców w domach. Cristina Aligas i Anna M. Margallo opisują ciekawe rezultaty długofalowych badań etnograficznych $\mathrm{w}$ podrozdziale zatytułowanym iPads, Emergent Readers and Families (iPady, początkujacy czytelnicy $i$ rodziny). Autorki zbadały cztery rodziny klasy średniej wykorzystujące iPady do wspólnego czytania z dzieckiem. Szczególną uwagę zwróciły na czas i miejsce wspólnego czytania, konfigurację i użycie iPada, proces nauki czytania oraz interakcję między dzieckiem, rodzicem oraz urządzeniem, wpływ interaktywnych zasobów aplikacji na doświadczenia czytelnicze. Neus Real i Cristina Correro rozpatrują debatę nad użyciem urządzeń dotykowych przez małe dzieci i opisują różnice $\mathrm{w}$ preferencjach młodych czytelników mających kontakt $\mathrm{z}$ urządzeniami $\mathrm{w}$ domu i w przedszkolu w zależności od przestrzeni, $\mathrm{w}$ jakiej się znajdują. Autorzy podkreślają znaczenie umożliwiania dzieciom poniżej siódmego roku życia nowego typu doświadczeń czytelniczych, które uzupełniają 
tradycyjną naukę czytania. Rozdział ten kończą Teresa Colomer i Karla Fernández de Gamboa Vázquez badaniami nad efektem wprowadzenia cyfrowych dzieł do szkolnej biblioteki. Autorzy zadali sobie pytanie, jak wpłynie to na nawyki czytelnicze, jakie będą preferencje dzieci, oraz jak ocenią te dzieła? Badania wykazały realną możliwość integracji cyfrowej literatury w klasowej bibliotece oraz korzystny wpływ jej wprowadzenia, nie umniejszając przy tym znaczenia drukowanych lektur.

Część piąta stanowi pewnego rodzaju podsumowanie publikacji i przedstawia refleksję nad tworzeniem tekstów cyfrowych. Kate Pullinger opisuje, jak stworzyła wraz Chrisem Josephem serię interaktywnych historii Inanimate Ali$c e$, jedną z najpopularniejszych cyfrowych historii na świecie. W ostatnim podrozdziale Change of Direction (Zmiana kierunku) Arnal Ballester rozpatruje głęboką społeczną i kulturową zmianę, bierze pod uwagę związek pomiędzy dziecięcym drukiem a cyfrową literaturą, grami wideo oraz ilustracjami. Podrozdział ten sugeruje nowe spojrzenie na zmianę związku między wiedzą i literacką kreacją.

Publikacja ta jest bogatym źródłem wiedzy dla wszystkich zainteresowanych zjawiskiem digitalizacji literatury dziecięcej, również tych niezaznajomionych z tematem, dzięki połączeniu rozdziałów teoretycznych z praktycznymi. Szczególnie wartościowa wydaje się dla rodziców oraz nauczycieli mających za zadanie wprowadzenie dziecka w świat literatury w obu formach. Dorośli stoją przed wyzwaniem pokazania dzieciom cyfrowych lektur, nie bagatelizując jednocześnie tradycyjnych dzieł w drukowanej formie. 